\title{
Market weight, slaughter age, and yield grade to determine economic carcass traits and primal cuts yield of Hanwoo beef
}

\author{
Ki-Mun Kwon ${ }^{1 \#, ~ K i m ~ M a r g a r e t t e ~ C . ~ N o g o y ~}{ }^{2 \#}$, Hwa-Eun Jeon ${ }^{1}$, Seung-Ju Han ${ }^{1}$, \\ Hee-Chan Woo ${ }^{1}$, Sung-Min Heo ${ }^{1}$, Hyoung Ki Hong ${ }^{2}$, Jae-lk Lee ${ }^{1,2}$, \\ Dong Hoon Lee ${ }^{3 *}$ and Seong Ho Choi ${ }^{2 *}$ \\ ${ }^{1}$ Korea Institute for Animal Products Quality Evaluation, Sejong 30100, Korea \\ ${ }^{2}$ Department of Animal Science, Chungbuk National University, Cheongju 28644, Korea \\ ${ }^{3}$ Department of Biosystems Engineering, Chungbuk National University, Cheongju 28644, Korea
}

Received: Nov 8, 2021

Revised: Dec 13, 2021

Accepted: Dec 22, 2021

\# $_{\text {These authors contributed equally to }}$ this work.

${ }^{*}$ Corresponding author Dong Hoon Lee

Department of Biosystems Engineering, Chungbuk National University,

Cheongju 28644, Korea.

Tel: +82-43-261-2579

E-mail: leedh@cbnu.ac.kr

\section{Seong Ho Choi}

Department of Animal Science, Chungbuk National University, Cheongju 28644, Korea.

Tel: +82-43-261-2544

E-mail: seongho@cbnu.ac.kr

Copyright $(\subset) 2022$ Korean Society of Animal Sciences and Technology. This is an Open Access article distributed under the terms of the Creative Commons Attribution Non-Commercial License (http:// creativecommons.org/licenses/by$\mathrm{nc} / 4.0 /$ ) which permits unrestricted non-commercial use, distribution, and reproduction in any medium, provided the original work is properly cited.

ORCID

Ki-Mun Kwon

https://orcid.org/0000-0001-8191-9016 Kim Margarette C. Nogoy

https://orcid.org/0000-0002-0958-7632

Hwa-Eun Jeon

https://orcid.org/0000-0003-1545-3558

\section{Abstract}

This study was conducted to evaluate the relationship among market weight, slaughter age, yield grade, and primal cut yield in Hanwoo. A total of 403 Hanwoo (Korean native cattle) was assessed for carcass traits such as carcass cold weight, backfat thickness, ribeye area, dressing percentage, yield index, and marbling score. The production yield of the individual major primal cuts of Hanwoo beef was also measured. Carcass cold weight, ribeye area, and backfat thickness, which affect meat quality increased with increased market weight $(p<$ $0.05)$. The production yield of the ten major primal cuts also increased with increased market weight $(p<0.05)$. In terms of slaughter age, carcass cold weight, ribeye area, and backfat thickness all increased from 25 months to 28-29 months, and the production yield of all prime cuts also increased with increasing slaughter age. According to the meat yield grade, carcass cold weight and backfat thickness increased from grade $\mathrm{A}$ to grade $\mathrm{C}$, although the ribeye area was not affected. The combined findings of the study suggest that slaughtering Hanwoo at the weight of $651-700 \mathrm{~kg}$ and $701-750$ and age of 28.23 and 29.83 months could be desirable to achieve the best quality and quantity grade of Hanwoo beef. However, the positive correlation of carcass cold weight and backfat thickness, and the negative correlation of the yield index according to primal cuts yield indicated that it is necessary to couple the slaughtering management of cattle with improved genetic and breeding method of Hanwoo to increase the production yield of the major prime cuts of Hanwoo beef.

Keywords: Hanwoo, Carcass traits, Market weight, Slaughter age, Yield grade, Correlation

\section{INTRODUCTION}

The Korean beef industry is one of the many developed countries that has been long showing trends into marketing individual muscle cuts for consumption [1,2]. In South Korea, Hanwoo beef is divided into 10 primal cuts and 39 minor beef cuts according to guidelines of labeling and division of beef and 
Seung-Ju Han

https://orcid.org/0000-0003-2126-9669

Hee-Chan Woo

https://orcid.org/0000-0003-3013-271X

Sung-Min Heo

https://orcid.org/0000-0003-4726-9958

Hyoung Ki Hong

https://orcid.org/0000-0003-3244-9307

Jae-lk Lee

https://orcid.org/0000-0002-6664-1869

Dong Hoon Lee

https://orcid.org/0000-0002-0582-1890

Seong Ho Choi

https://orcid.org/0000-0001-8869-0218

\section{Competing interests}

The authors have no potential personal or financial conflict of interest relevant to this article to report.

Funding sources

This study was funded by the Korea Institute for Animal Products Quality Evaluation and by the National Research Foundation in Korea (grant number: NRF2018R1D1A3B07048219)

\section{Acknowledgements}

This study was funded by the Korea Institute for Animal Products Quality Evaluation and by the National Research Foundation in Korea (grant number: NRF2018R1D1A3B07048219).

Availability of data and material Upon reasonable request, the datasets of this study can be available from the corresponding author.

Authors' contributions

Concept: Kwon KM, Nogoy KMC, Lee DH, Choi SH.

Data curation: Kwon KM, Jeon HE, Han SJ, Woo HC, Heo SM, Hong HK, Lee JI.

Formal Analysis: Kwon KM.

Methodology: Kwon KM, Jeon HE, Han SJ, Woo HC, Heo SM, Hong HK, Lee JI.

Validation: Nogoy KMC, Lee DH, Choi SH.

Writing: original draft: Kwon KM, Nogoy KMC.

Writing: review \& editing: Kwon KM, Nogoy KMC, Jeon HE, Han SJ, Woo HC, Heo SM, Hong HK, Lee Jl, Lee DH, Choi SH.

Ethics approval and consent to participate All experimental procedures complied with the guidelines of the Korean Animal Protection Law (Article 6), and the Livestock Sanitation Control Act Law (Annex I). pork meat in Korea [3]. A study on the chemical composition and meat quality traits of the 10 primal cuts showed that tenderloin, loin, sirloin, and ribs had the highest overall acceptability [4], and Seo et al. reported that carcass length and the 7th to 8th thoracic vertebrae girth showed to be the most important traits affecting primal cut yields [5]. These recent studies have shown that meat quality and carcass yield traits differ according to the primal cuts. Under the Korean meat market, meat quality and carcass yield are the main drivers that influence marketing price in which the latter greatly affects the profits in beef meat.

The Hanwoo feeding program is heavily reliant on a high-energy feed ration from 6 to 29 months of age, and it has been reported that a 29 -month old endpoint is the suitable economic feeding period for Hanwoo [6]. However, due to demand for increased marbling scores (MS), livestock farmers have increased the slaughtering age of Hanwoo from 30.2 months in 2009 to 32.5 months in 2014 [7]. MS and carcass weight steadily increased with the increasing age of slaughter: 26,28 , and 30 months [8]. In some instances such as when meat market prices are low, farmers extend the feeding past normally the optimum market weights of the cattle. The market weight of Hanwoo has increased from $425 \mathrm{~kg}$ in the early 1980s [9] to $694 \mathrm{~kg}$ in 2011 [10]. The average feeding cost of Hanwoo has also increased from 2,170,000 won/head in 2010 to 2,982,000 won/ head in 2016 [11]. The extension of the feeding period along with the inflation in feed prices poses an economic challenge to livestock farmers and consumers alike.

In this regard, it is indispensable to recognize the influence of market weight and slaughter age of Hanwoo to prime cuts yields of Hanwoo beef and to understand the relative importance of the relationship between carcass traits and yield grade. Therefore, the objective of this study was to mainly determine the influence of market weight, slaughter age, and yield grade on the yield of ten primal cuts and economic carcass traits. In addition, the correlation of the carcass traits with the yield of the primal cuts was analyzed to better understand the contributing factors that affect the economic carcass characteristics of Hanwoo.

\section{MATERIALS AND METHODS}

\section{Animal management}

A total of 403 Hanwoo steers (Korean native cattle) at age of 24 to 35 months was slaughtered at three abattoir locations: Nonghyup Eumseong Livestock Products Market, Nonghyup Bucheon Livestock Products Market, and Hyupshin Foods from April to July 2021. The commercial slaughter of the Hanwoo steers followed the guidelines of the Korean Animal Protection Law (Article 6), and the Livestock Sanitation Control Act Law (Annex I).

\section{Carcass characteristics evaluation and prime cuts yield measurement}

Live weight of the Hanwoo cattle was measured for each head before slaughter after being shipped from the farm to each abattoir. After $24 \mathrm{~h}$ post-mortem in a cold room $\left(1^{\circ} \mathrm{C}\right)$, carcass cold weight $(\mathrm{CCW})$ was measured and dressing percentage was calculated, and the left side of the carcass was ribbed between the thoracic vertebra and the first lumbar vertebra to measure the backfat thickness (BFT), ribeye area (REA), and the quality traits. BFT was measured over the medial third part of the REA. The area of the ribeye was determined at the surface of the cut using a standard grid. Marbling was scored in the REA from 1 as rare to 9 as abundant according to the standard [12,13]. Yield grade was determined by the CCW, adjusted BFT, and the REA.

The yield index was calculated by the following equation: 
Yield index $=$

$\underline{\left(11.06398-[1.25149 \times \text { Backfat thickness }(\mathrm{mm})]+\left[0.28293 \times \text { Ribeye area }\left(\mathrm{cm}^{2}\right)\right]+[0.54768 \times \text { Carcass cold weight }(\mathrm{kg})]\right)}$

( Carcass cold weight $(\mathrm{kg}) \times 100)$

After measuring the carcass yield traits and grading the yield, the carcasses were dissected into 10 major primal cuts according to guidelines of labeling and division of beef and pork meat in Korea [3]. The weight was measured after sampling the 10 primal cuts (tenderloin, sirloin, striploin, chuck, shoulder, bottom round, top round, brisket, shank, and rib) from which all visible fat and bone were separated and weighed.

\section{Statistical analysis}

Market weight, slaughter age, and yield grade as functions of each carcass traits (CCW, REA, BFT, yield index, dressing percentage, MS, meat yield, fat yield, and bone yield) were tested by analysis of variance using a general linear model (GLM) performed using SAS [14]. Significance levels of the least square mean for each trait were separated by probability at a 5\% level. Correlation analysis of the slaughter age, market weight, and of each carcass weight to the primal cut of the Hanwoo was estimated through Pearson's correlation. Multi regression analysis was performed to determine how much the economic carcass traits affect the ten primal cut yields, and semi-partial analysis was used to indicate the contribution.

\section{RESULTS AND DISCUSSION}

\section{Carcass yield traits and primal cut yield according to market weight}

It is important to make a careful decision on the market weight of the Hanwoo or any breed of beef cattle due to its confounding effect on beef quality, yield grade, and economic aspects. Changes in the economic carcass characteristics according to the market weight of Hanwoo beef were shown in Table 1. Results showed that the CCW, REA, and BFT increased as the market weight of the Hanwoo increased $(p<0.05)$. Consequently, the meat yield index (MYI) tended to decrease as the market weight increased $(p<0.05)$. The findings in the MYI of the present study were similarly observed in a previous study which reported that there was a significant decrease in the yield index

Table 1. Least square means ( $\pm S D$ ) of carcass traits according to Hanwoo market weight

\begin{tabular}{|c|c|c|c|c|c|c|}
\hline \multirow{2}{*}{ Carcass traits } & \multicolumn{6}{|c|}{ Market weight (kg) } \\
\hline & $650 \geq(n=23)$ & $651-700(n=69)$ & $701-750(n=88)$ & $751-800(n=113)$ & $801-850(n=63)$ & $851 \leq(n=47)$ \\
\hline Slaughter age (month) & $28.83 \pm 3.01^{\mathrm{cd}}$ & $28.23 \pm 2.71^{d}$ & $29.83 \pm 2.66^{\mathrm{abc}}$ & $29.62 \pm 2.33^{\text {bc }}$ & $30.24 \pm 2.41^{\mathrm{ab}}$ & $30.79 \pm 2.28^{a}$ \\
\hline Carcass cold weight $(\mathrm{kg})$ & $367.43 \pm 15.78^{f}$ & $397.72 \pm 14.49^{\mathrm{e}}$ & $425.64 \pm 15.90^{d}$ & $458.56 \pm 17.25^{c}$ & $490.95 \pm 15.50^{b}$ & $529.36 \pm 25.86^{\circ}$ \\
\hline Ribeye area $\left(\mathrm{cm}^{2}\right)$ & $78.78 \pm 5.68^{d}$ & $84.43 \pm 7.57^{c}$ & $87.14 \pm 7.58^{c}$ & $91.93 \pm 8.21^{b}$ & $93.4 \pm 7.11^{\mathrm{ab}}$ & $95.77 \pm 8.03^{\mathrm{a}}$ \\
\hline Backfat thickness (mm) & $9.83 \pm 4.90^{d}$ & $11.83 \pm 3.78^{c}$ & $12.82 \pm 4.65^{\mathrm{bc}}$ & $14.19 \pm 4.80^{\mathrm{b}}$ & $16.70 \pm 5.99^{\mathrm{a}}$ & $17.19 \pm 5.83^{\mathrm{a}}$ \\
\hline Yield index ${ }^{1)}$ & $62.53 \pm 1.69^{a}$ & $61.85 \pm 1.31^{\mathrm{b}}$ & $61.42 \pm 1.49^{\text {bc }}$ & $61.01 \pm 1.46^{c}$ & $60.16 \pm 1.63^{d}$ & $59.95 \pm 1.50^{d}$ \\
\hline Dressing percentage (\%) & $58.84 \pm 2.06$ & $58.65 \pm 1.77$ & $58.66 \pm 1.73$ & $59.22 \pm 1.82$ & $59.35 \pm 1.55$ & $59.40 \pm 1.63$ \\
\hline Marbling score ${ }^{2)}$ & $3.35 \pm 1.11^{\mathrm{b}}$ & $3.80 \pm 1.30^{\mathrm{ab}}$ & $3.77 \pm 1.24^{\mathrm{ab}}$ & $4.01 \pm 1.24^{\mathrm{a}}$ & $4.08 \pm 1.08^{\mathrm{a}}$ & $3.96 \pm 1.18^{\mathrm{a}}$ \\
\hline Primal cuts yield (kg) & $247.65 \pm 11.15^{f}$ & $260.81 \pm 11.73^{\mathrm{e}}$ & $277.23 \pm 12.72^{d}$ & $295.41 \pm 13.41^{c}$ & $311.44 \pm 15.08^{b}$ & $335.32 \pm 19.10^{\circ}$ \\
\hline Fat yield $(\mathrm{kg})$ & $73.05 \pm 10.54^{f}$ & $88.69 \pm 9.78^{\mathrm{e}}$ & $96.78 \pm 14.64^{d}$ & $108.33 \pm 16.21^{c}$ & $123.19 \pm 14.84^{b}$ & $132.49 \pm 18.27^{\circ}$ \\
\hline Bone yield $(\mathrm{kg})$ & $37.58 \pm 2.42^{d}$ & $38.93 \pm 3.28^{d}$ & $41.62 \pm 3.35^{\mathrm{c}}$ & $44.28 \pm 4.30^{\mathrm{b}}$ & $45.45 \pm 3.24^{b}$ & $49.93 \pm 5.36^{a}$ \\
\hline
\end{tabular}

${ }^{1}$ Yield index: $\left(11.06398-[1.25149 \times\right.$ Backfat thickness $(\mathrm{mm})]+\left[0.28293 \times\right.$ Ribeye area $\left(\mathrm{cm}^{2}\right)+[0.54768 \times$ Carcass cold weight $\left.(\mathrm{kg})]\right) \div($ Carcass cold weight $(\mathrm{kg}) \times 100)$.

${ }^{2)}$ Marbling score: 1-trace, 9-very abundant.

${ }^{a-f}$ Means within the same row with different superscript are statistically different $(p<0.05)$. 
of the Hanwoo as the market weight increased $[15,16]$. The tendency of the market weight to reduce MYI could be due to the increased BFT in this study. The increase in BFT could directly increase the market weight of Hanwoo but could also cause an indirect decrease in the MYI of the beef cattle. As evidenced, the lowest market weight $(650 \mathrm{~kg})$ showed the lowest BFT (9.83) and the highest MYI (62.53). The dressing percentage observed in this study ranged from 58.65 to 59.40. Although the observed dressing percentage in this study was lower than the optimized 60.64 dressing percentage reported [17], there were no significant differences observed among the different market weights of the Hanwoo. In terms of marbling, the MS of Hanwoo beef increased significantly with increasing market weight. The highest MS of 3.96 was observed in Hawoo with the market weight of $851 \mathrm{~kg}$ < and the lowest MS of 3.35 was observed in Hanwoo with the market weight of $650 \mathrm{~kg}>$. In the recent review of Park et el. [18], although the highest market weight reported was $591 \mathrm{~kg}$, it was reported that the MS generally increased with market weight in several breeds of cattle. The overall yield in terms of the whole prime cuts, fat weight, and bone weight was observed to significantly increase with market weight $(p<0.05)$ consistent with the previous study of Kim et al. [19]. More specifically, the lowest primal cuts yield of $247.65 \mathrm{~kg}$ was observed at the lowest market weight $(650 \geq \mathrm{kg})$ and the highest yield of $335.32 \mathrm{~kg}$ was observed at the highest market weight $(851 \leq \mathrm{kg})$. Fat weight yield ranged from $73.05 \mathrm{~kg}$ to $132.49 \mathrm{~kg}$, whereas bone yield ranged from $37.58 \mathrm{~kg}$ to $49.93 \mathrm{~kg}$.

The changes in the yield of the individual Hanwoo prime cuts according to market weight were presented (Table 2). The average primal cuts yield was 5.40 to $6.84 \mathrm{~kg}$ for tenderloin, 29.81 to $39.99 \mathrm{~kg}$ for sirloin, 7.45 to $10.06 \mathrm{~kg}$ to strip loin, 13.18 to $18.64 \mathrm{~kg}$ for chuck, 21.56 to $28.29 \mathrm{~kg}$ for shoulder, 20.19 to $26.54 \mathrm{~kg}$ for the bottom round, 30.96 to $41.53 \mathrm{~kg}$ for top round, 39.23 to $52.46 \mathrm{~kg}$ for the brisket, 18.90 to $23.29 \mathrm{~kg}$ for the shank, and 58.82 to $85.06 \mathrm{~kg}$ for ribs. The yield of the individual primal cut consistently increased as the market weight of Hanwoo increased ( $p$ $<0.05$ ). It was generally expected that the carcass traits and the yield of the individual primal cut increased with market weight. Heavier beef cattle produce heavier carcass weight, consequently resulting in heavier lean meat (prime cuts), fat and bone yield, larger ribeye area, thicker backfat, and accordingly tending to lower the yield index. As higher quality grade is expected from heavier carcasses with thicker backfat and larger ribeye areas, a higher market weight of Hanwoo could result in a better beef quality grade. Some studies reported that carcasses with larger ribeye areas resulted in a lower United States Department of Agriculture (USDA) quality grade [20,21], but a high positive correlation in market weight, marbling, and REA was found according to the

Table 2. Least square means $( \pm S D)$ of ten major primal cuts yields according to Hanwoo market weight

\begin{tabular}{|c|c|c|c|c|c|c|}
\hline \multirow{2}{*}{ Item } & \multicolumn{6}{|c|}{ Market weight (kg) } \\
\hline & $650 \geq(n=23)$ & $651-700(n=69)$ & $701-750(n=88)$ & $751-800(n=113)$ & $801-850(n=63)$ & $851 \leq(n=47)$ \\
\hline Tenderloin (kg) & $5.40 \pm 0.35^{\mathrm{e}}$ & $5.52 \pm 0.37^{e}$ & $5.89 \pm 0.51^{d}$ & $6.12 \pm 0.47^{c}$ & $6.41 \pm 0.50^{b}$ & $6.84 \pm 0.55^{a}$ \\
\hline Strip loin (kg) & $7.45 \pm 0.58^{f}$ & $7.90 \pm 0.68^{\mathrm{e}}$ & $8.35 \pm 0.75^{d}$ & $8.96 \pm 0.82^{c}$ & $9.47 \pm 0.81^{b}$ & $10.06 \pm 0.84^{a}$ \\
\hline Chuck (kg) & $13.18 \pm 1.41^{d}$ & $13.84 \pm 1.53^{\mathrm{d}}$ & $14.75 \pm 1.91^{\mathrm{C}}$ & $16.14 \pm 1.78^{b}$ & $16.79 \pm 1.76^{b}$ & $18.64 \pm 2.27^{\mathrm{a}}$ \\
\hline Top round $(\mathrm{kg})$ & $30.96 \pm 2.09^{f}$ & $32.26 \pm 2.08^{\mathrm{e}}$ & $34.54 \pm 2.57^{d}$ & $36.86 \pm 2.95^{\mathrm{c}}$ & $38.91 \pm 2.55^{\mathrm{b}}$ & $41.53 \pm 2.91^{\mathrm{a}}$ \\
\hline Brisket (kg) & $39.23 \pm 3.70^{f}$ & $40.79 \pm 3.70^{\mathrm{e}}$ & $43.65 \pm 3.45^{d}$ & $45.75 \pm 3.93^{c}$ & $48.00 \pm 4.360^{b}$ & $52.46 \pm 4.80^{a}$ \\
\hline Shank (kg) & $18.90 \pm 2.05^{\mathrm{d}}$ & $19.28 \pm 2.02^{d}$ & $20.21 \pm 1.71^{\mathrm{C}}$ & $20.99 \pm 1.92^{c}$ & $21.83 \pm 2.32^{b}$ & $23.29 \pm 2.68^{\mathrm{a}}$ \\
\hline $\operatorname{Rib}(\mathrm{kg})$ & $58.82 \pm 4.09^{f}$ & $64.17 \pm 3.86^{\mathrm{e}}$ & $68.51 \pm 4.76^{d}$ & $73.69 \pm 5.08^{c}$ & $78.99 \pm 5.61^{\mathrm{b}}$ & $85.06 \pm 7.40^{\mathrm{a}}$ \\
\hline
\end{tabular}

${ }^{a-f}$ Means within the same row with different superscripts are statistically different $(p<0.05)$. 
Hanwoo grading system [12]. Slaughtering at the weight of 651-700 and 701-750 at slaughtering age of 28.23 and 29.83 months, respectively, might be desirable to achieve the best quality and quantity grade of Hanwoo beef.

\section{Carcass yield traits and primal cut yield according to slaughter age}

Changes in the economic carcass characteristics according to the slaughter age of Hanwoo beef were shown in Table 3. Results showed that the market weight and CCW increased from 25 months to 30-31 months but there were no changes observed in both the market weight and CCW from 30-31 months to 34 months. Similar to the report of Yoon et al. [22], the CCW has stopped progressing after reaching 28 months of age. The REA increased from 25 months to 26-27 months but has stopped increasing upon reaching 28-29 months. The BFT has shown consistent thickness measurement from 25 months to 32-33 and has slightly increased at the age of 34 months or older. In the Japanese black cattle, a similar observation was found where the CCW, REA, and BFT did not show significant differences at slaughter ages of 30 to 34 months of age [23]. The overall prime cuts yield and the fat yield increased from 25 months to $28-29$ months and have stopped progressing from then to 34 months. Bone yield, on the other hand, increased from 25 months to $26-27$ months and kept a steady yield from then to 34 months. The changes in the lean meat production of the individual primal cuts of Hanwoo beef according to slaughter age were shown in Table 4. The average primal cuts yield was 5.49 to $6.34 \mathrm{~kg}$ for tenderloin, 31.43 to $36.58 \mathrm{~kg}$ for sirloin, 7.86 to $9.08 \mathrm{~kg}$ to strip loin, 13.92 to $16.35 \mathrm{~kg}$ for chuck, 22.37 to $25.67 \mathrm{~kg}$ for shoulder, 20.93 to $24.08 \mathrm{~kg}$ for the bottom round, 31.70 to $37.71 \mathrm{~kg}$ for top round, 40.88 to 45.94 $\mathrm{kg}$ for the brisket, 18.93 to $21.46 \mathrm{~kg}$ for the shank, and 67.09 to $72.43 \mathrm{~kg}$ for ribs. It can be found in this result that the yield of prime cuts tenderloin, sirloin, shoulder, bottom round, and top round continuously increased from 25 months to 34 months. Strip loin, chuck, brisket, shanks, and ribs increased from 25 months to 26-27 months and kept a steady lean meat yield from then on to 34 months. In terms of marbling quality, the MS recorded in this study according to slaughter age ranged from 3.47 to 4.01 and there were no significant differences observed among the different slaughter ages of the Hanwoo beef. Contrary to studies, the MS generally increased with slaughter age in Korean cattle [18]. The MS of Korean steers increased from 6.0 to 7.06 at 26 to 31 months

Table 3. Least square means ( $\pm S D$ ) of carcass traits according to slaughter age

\begin{tabular}{|c|c|c|c|c|c|c|}
\hline \multirow{2}{*}{ Trait } & \multicolumn{6}{|c|}{ Slaughter age (month) } \\
\hline & $25 \geq(n=15)$ & $26-27(n=87)$ & $28-29(n=96)$ & $30-31(n=106)$ & $32-33(n=71)$ & $34 \leq(n=28)$ \\
\hline Market weight (kg) & $687.13 \pm 54.27^{c}$ & $738.11 \pm 65.87^{b}$ & $751.92 \pm 70.22^{\mathrm{ab}}$ & $777.99 \pm 74.82^{a}$ & $781.51 \pm 74.50^{\mathrm{a}}$ & $779.86 \pm 76.06^{\mathrm{a}}$ \\
\hline $\operatorname{REA}\left(\mathrm{cm}^{2}\right)$ & $84.67 \pm 9.01^{b}$ & $90.43 \pm 8.62^{\mathrm{a}}$ & $89.39 \pm 9.89^{a}$ & $89.40 \pm 7.86^{a}$ & $89.75 \pm 9.62^{\mathrm{a}}$ & $89.75 \pm 7.22^{\mathrm{a}}$ \\
\hline $\mathrm{BFT}(\mathrm{mm})$ & $12.53 \pm 4.94^{b}$ & $13.14 \pm 4.83^{\mathrm{b}}$ & $13.28 \pm 4.97^{b}$ & $14.40 \pm 5.43^{\mathrm{ab}}$ & $14.66 \pm 5.29^{\mathrm{ab}}$ & $16.43 \pm 7.26^{a}$ \\
\hline Marbling score ${ }^{2}$ & $3.47 \pm 0.99$ & $3.94 \pm 1.40$ & $3.77 \pm 1.19$ & $3.95 \pm 1.18$ & $4.01 \pm 1.18$ & $3.79 \pm 1.07$ \\
\hline PCY (kg) & $262.89 \pm 21.32^{c}$ & $283.47 \pm 26.20^{b}$ & $288.84 \pm 28.11^{\mathrm{ab}}$ & $294.66 \pm 26.55^{\mathrm{ab}}$ & $294.85 \pm 28.90^{\mathrm{ab}}$ & $298.14 \pm 31.49^{a}$ \\
\hline Fat yield $(\mathrm{kg})$ & $94.22 \pm 18.72^{c}$ & $99.99 \pm 17.75^{\mathrm{bc}}$ & $101.99 \pm 20.87^{\mathrm{abc}}$ & $111.76 \pm 23.45^{\mathrm{a}}$ & $109.90 \pm 21.87^{\mathrm{ab}}$ & $106.83 \pm 23.84^{\mathrm{ab}}$ \\
\hline Bone yield (kg) & $38.96 \pm 3.35^{\mathrm{b}}$ & $42.13 \pm 5.03^{\mathrm{a}}$ & $43.39 \pm 5.28^{\mathrm{a}}$ & $43.76 \pm 4.76^{\mathrm{a}}$ & $44.13 \pm 4.63^{\mathrm{a}}$ & $44.30 \pm 6.95^{\mathrm{a}}$ \\
\hline
\end{tabular}

${ }^{1}$ Yield index: $\left(11.06398-[1.25149 \times\right.$ Backfat thickness $(\mathrm{mm})]+\left[0.28293 \times\right.$ Ribeye area $\left(\mathrm{cm}^{2}\right)+[0.54768 \times$ Carcass cold weight $\left.(\mathrm{kg})]\right) \div($ Carcass cold weight $(\mathrm{kg}) \times 100)$.

${ }^{2)}$ Marbling score: 1-trace, 9-very abundant.

${ }^{a-c}$ Means within the same row with different superscript are statistically different $(p<0.05)$.

CCW, carcass cold weight; REA, ribeye area; BFT, backfat thickness; DP, dressing percentage; MS, marbling score; PCY, primal cuts yield 
Table 4. Least square means $( \pm S D)$ of ten major primal cuts yields according to slaughter age

\begin{tabular}{|c|c|c|c|c|c|c|}
\hline \multirow{2}{*}{ Item } & \multicolumn{6}{|c|}{ Slaughter age (month) } \\
\hline & $25 \geq(n=15)$ & $26-27(n=87)$ & $28-29(n=96)$ & $30-31(n=106)$ & $32-33(n=71)$ & $34 \leq(n=28)$ \\
\hline Tenderloin (kg) & $5.49 \pm 0.39^{c}$ & $5.98 \pm 0.60^{b}$ & $6.01 \pm 0.63^{b}$ & $6.12 \pm 0.61^{\mathrm{ab}}$ & $6.12 \pm 0.61^{\mathrm{ab}}$ & $6.34 \pm 0.70^{a}$ \\
\hline Sirloin $(\mathrm{kg})$ & $31.43 \pm 2.88^{\mathrm{c}}$ & $34.32 \pm 3.60^{\mathrm{b}}$ & $34.62 \pm 3.89^{b}$ & $35.35 \pm 3.48^{\mathrm{ab}}$ & $35.63 \pm 4.27^{\mathrm{ab}}$ & $36.58 \pm 3.65^{\mathrm{a}}$ \\
\hline Strip loin (kg) & $7.86 \pm 0.62^{b}$ & $8.61 \pm 0.96^{a}$ & $8.76 \pm 1.18^{\mathrm{a}}$ & $8.79 \pm 1.00^{\mathrm{a}}$ & $9.00 \pm 1.08^{\mathrm{a}}$ & $9.08 \pm 1.07^{\mathrm{a}}$ \\
\hline Chuck (kg) & $13.92 \pm 1.72^{b}$ & $15.22 \pm 2.41^{\mathrm{a}}$ & $15.64 \pm 2.22^{\mathrm{a}}$ & $15.99 \pm 2.13^{\mathrm{a}}$ & $15.84 \pm 2.59^{\mathrm{a}}$ & $16.35 \pm 2.92^{\mathrm{a}}$ \\
\hline Shoulder (kg) & $22.37 \pm 1.71^{\mathrm{C}}$ & $24.09 \pm 2.65^{b}$ & $24.62 \pm 2.71^{\mathrm{ab}}$ & $25.16 \pm 2.35^{\mathrm{ab}}$ & $25.03 \pm 2.68^{\mathrm{ab}}$ & $25.67 \pm 3.35^{\mathrm{a}}$ \\
\hline Bottom round $(\mathrm{kg})$ & $20.93 \pm 1.50^{c}$ & $22.67 \pm 2.51^{\mathrm{b}}$ & $23.16 \pm 2.58^{\mathrm{ab}}$ & $23.26 \pm 2.43^{\mathrm{ab}}$ & $23.5 \pm 2.63^{\mathrm{ab}}$ & $24.08 \pm 2.91^{\mathrm{a}}$ \\
\hline Top round $(\mathrm{kg})$ & $31.70 \pm 2.98^{\mathrm{c}}$ & $35.45 \pm 3.93^{b}$ & $35.81 \pm 3.91^{\mathrm{b}}$ & $36.61 \pm 3.78^{\mathrm{ab}}$ & $36.78 \pm 4.12^{\mathrm{ab}}$ & $37.71 \pm 4.14^{\mathrm{a}}$ \\
\hline Brisket (kg) & $40.88 \pm 4.13^{b}$ & $43.95 \pm 5.12^{\mathrm{a}}$ & $45.74 \pm 5.24^{\mathrm{a}}$ & $45.83 \pm 5.27^{\mathrm{a}}$ & $45.70 \pm 5.44^{\mathrm{a}}$ & $45.94 \pm 6.15^{\mathrm{a}}$ \\
\hline Shank (kg) & $18.93 \pm 1.81^{b}$ & $20.72 \pm 2.32^{\mathrm{a}}$ & $20.63 \pm 2.41^{\mathrm{a}}$ & $20.97 \pm 2.32^{\mathrm{a}}$ & $21.05 \pm 2.39^{\mathrm{a}}$ & $21.46 \pm 2.94^{\mathrm{a}}$ \\
\hline Rib (kg) & $67.09 \pm 8.48^{b}$ & $70.22 \pm 7.86^{\mathrm{ab}}$ & $71.43 \pm 8.37^{\mathrm{a}}$ & $74.29 \pm 8.95^{\mathrm{a}}$ & $73.75 \pm 9.41^{\mathrm{a}}$ & $72.43 \pm 9.42^{\mathrm{a}}$ \\
\hline
\end{tabular}

${ }^{a-c}$ Means within the same row with different superscripts are statistically different $(p<0.05)$.

of slaughter age while the MS of the Korean beef cattle regardless of sex increased 4.9 to 5.7 at 26 to 35 months of slaughter age [24]. Summing up, the carcass yield traits of Hanwoo beef such as market weight, CCW, REA, BFT, overall and individual prime cut yield, fat weight, and bone weight progressed until at the age of 27 to 28 months. As evidenced by the carcass yield traits and the comparable MS among different slaughter ages, this study suggests that there was no negative impact at slaughtering Hanwoo beef cattle at a young age. Reducing the slaughter age to 28 months which is 4.5 months shorter than the commonly practiced slaughter age of 32.5 months $[7,11]$ showed the best results of carcass yield traits without compromising the quality of marbling of Hanwoo beef. The slaughter age at 28 months would be economically sufficient as the carcass yield traits and the individual prime cut yield was consistently the same across all slaughter age from 28 to 34 months. Studies by Yoon et al. [22] and Kim et al. [25] also suggested that at 28 and 29-month old endpoints, respectively, is a suitable slaughter age for Hanwoo. In addition, it was reported that the optimum slaughter age for Korean cattle to give the highest profit was 28 months irrespective of the gender of the animals $[18,26]$.

\section{Carcass yield traits and primal cut yield according to yield grade}

The Korean grading system of meat yield consists of three grades: A, B, C grades depending on the MYI computed from REA, BFT, and CCW, and with grade A as the highest. Changes in the economic carcass characteristics according to the yield grade of Hanwoo beef were shown in Table 5. The CCW and BFT were found to decrease as the grade increased $(p<0.05)$, while the REA did not show a significant difference with yield grade. The MYI increased with increasing yield grade in which grades A, B, and C have shown yield index of 63.21, 61.44, and 58.99, respectively. The combination of increased CCW and BFT, and decreased yield index was consistent with the findings of the previous studies [27-29]. The dressing percentage was highest in grade $\mathrm{C}$ at 59.77 $(p<0.05)$ and there was no difference between grades A and B. The primal cuts yield was lowest at $277.74 \mathrm{~kg}$ in grade A. The fat yield increased significantly as the grade decreased $(p<0.05)$, while the bone yield did not differ in yield grades. Most importantly, the market weight of grades A, B, and $\mathrm{C}$ were $708.27 \mathrm{~kg}, 757.54 \mathrm{~kg}$, and $800.11 \mathrm{~kg}$, showing an increasing trend with decreasing grades $(p<0.05)$. Slaughter age by yield grade was 28.58 months for grade A, 29.68 months for grade $\mathrm{B}$, and 30.17 months for grade $\mathrm{C}$, in which grade $\mathrm{A}$ was found significantly higher than $\mathrm{B}$ and C. Similarly, slaughter age of 929.1 days for Grade A, 940.7 days for Grade B, and 961.4 days for Grade $\mathrm{C}$ was reported by Yoon et al. [22]. These results signify that prolonging the slaughter 
Table 5. Least square means ( \pm SD) of carcass traits according to yield grade

\begin{tabular}{lccc}
\hline \multirow{2}{*}{\multicolumn{1}{c}{ Trait }} & \multicolumn{3}{c}{ Yield grade } \\
\cline { 2 - 4 } & $\mathbf{A}(\mathbf{n}=\mathbf{7 4})$ & $\mathbf{B}(\mathbf{n}=\mathbf{2 1 5})$ & $\mathbf{C}(\mathbf{n}=\mathbf{1 1 4})$ \\
\hline Market weight $(\mathrm{kg})$ & $708.27 \pm 60.91^{\mathrm{c}}$ & $757.54 \pm 66.31^{\mathrm{b}}$ & $800.11 \pm 74.46^{\mathrm{a}}$ \\
Age of slaughter (month) & $28.58 \pm 2.41^{\mathrm{b}}$ & $29.68 \pm 2.56^{\mathrm{a}}$ & $30.17 \pm 2.69^{\mathrm{a}}$ \\
Carcass cold weight $(\mathrm{kg})$ & $414.18 \pm 37.79^{\mathrm{c}}$ & $445.65 \pm 42.48^{\mathrm{b}}$ & $478.19 \pm 46.86^{\mathrm{a}}$ \\
Ribeye area $\left(\mathrm{cm}^{2}\right)$ & $89.43 \pm 9.69$ & $89.35 \pm 8.86$ & $89.92 \pm 8.40$ \\
Backfat thickness $(\mathrm{mm})$ & $7.82 \pm 2.03^{\mathrm{c}}$ & $12.50 \pm 2.13^{\mathrm{b}}$ & $20.76 \pm 3.94^{\mathrm{a}}$ \\
Yield index & $63.21 \pm 0.56^{\mathrm{a}}$ & $61.44 \pm 0.61^{\mathrm{b}}$ & $58.99 \pm 1.07^{\mathrm{c}}$ \\
Dressing percentage $(\%)$ & $58.48 \pm 1.76^{\mathrm{b}}$ & $58.81 \pm 1.61^{\mathrm{b}}$ & $59.77 \pm 1.82^{\mathrm{a}}$ \\
Marbling score & $3.53 \pm 1.15^{\mathrm{b}}$ & $3.88 \pm 1.39^{\mathrm{a}}$ & $4.14 \pm 0.79^{\mathrm{a}}$ \\
Primal cuts yield $(\mathrm{kg})$ & $277.74 \pm 25.13^{\mathrm{b}}$ & $290.32 \pm 27.27^{\mathrm{a}}$ & $297.19 \pm 29.47^{\mathrm{a}}$ \\
Fat yield $(\mathrm{kg})$ & $83.07 \pm 12.35^{\mathrm{c}}$ & $101.76 \pm 15.19^{\mathrm{b}}$ & $127.35 \pm 17.86^{\mathrm{a}}$ \\
Bone yield $(\mathrm{kg})$ & $43.09 \pm 4.93$ & $43.21 \pm 5.43$ & $43.39 \pm 4.77$
\end{tabular}

${ }^{1)}$ Yield index : $\left(11.06398-[1.25149 \times\right.$ Backfat thickness $(\mathrm{mm})]+\left[0.28293 \times\right.$ Ribeye area $\left(\mathrm{cm}^{2}\right)+[0.54768 \times$ Carcass cold weight $(\mathrm{kg})]) \div($ Carcass cold weight $(\mathrm{kg}) \times 100)$.

${ }^{2)}$ Marbling score: 1-trace, 9-very abundant.

${ }^{a-c}$ Means within the same row with different superscript are statistically different $(p<0.05)$.

Table 6. Least square means ( \pm SD) of ten major primal cuts yields according to yield grade

\begin{tabular}{|c|c|c|c|}
\hline \multirow{2}{*}{ Item } & \multicolumn{3}{|c|}{ Yield grade } \\
\hline & $A(n=74)$ & $B(n=215)$ & $C(n=114)$ \\
\hline Tenderloin (kg) & $5.97 \pm 0.58$ & $6.10 \pm 0.65$ & $6.04 \pm 0.60$ \\
\hline Sirloin (kg) & $33.78 \pm 3.72^{\mathrm{b}}$ & $34.90 \pm 3.64^{\mathrm{a}}$ & $35.78 \pm 4.11^{\mathrm{a}}$ \\
\hline Strip loin (kg) & $8.58 \pm 1.05$ & $8.78 \pm 1.02$ & $8.86 \pm 1.14$ \\
\hline Chuck (kg) & $15.30 \pm 2.34$ & $15.79 \pm 2.31$ & $15.67 \pm 2.52$ \\
\hline Shoulder (kg) & $24.23 \pm 2.58$ & $24.73 \pm 2.71$ & $24.97 \pm 2.68$ \\
\hline Bottom round (kg) & $23.04 \pm 2.40$ & $23.03 \pm 2.58$ & $23.34 \pm 2.69$ \\
\hline Top round $(\mathrm{kg})$ & $35.44 \pm 3.62^{b}$ & $35.90 \pm 4.00^{\mathrm{ab}}$ & $36.89 \pm 4.23^{\mathrm{a}}$ \\
\hline Brisket (kg) & $43.41 \pm 5.02^{b}$ & $45.64 \pm 5.20^{\mathrm{a}}$ & $45.55 \pm 5.73^{\mathrm{a}}$ \\
\hline Shank (kg) & $20.29 \pm 1.87^{\mathrm{b}}$ & $20.61 \pm 2.42^{\mathrm{b}}$ & $21.51 \pm 2.56^{a}$ \\
\hline $\mathrm{Rib}(\mathrm{kg})$ & $65.36 \pm 6.80^{c}$ & $72.47 \pm 7.88^{\mathrm{b}}$ & $76.25 \pm 9.12^{\mathrm{a}}$ \\
\hline
\end{tabular}

${ }^{a-c}$ Means within the same row with different superscripts are statistically different $(p<0.05)$.

age could lower the yield grade of Hanwoo. It has been reported that the average slaughtering age in the Hanwoo industry has shifted from 30.2 months in 2009 to 32.5 months in 2014, and this extension of feeding period has shown a decrease in the rate of yield grade A from $43 \%$ in 2003 to $26.1 \%$ in 2015 [7]. Hence, establishing the slaughter age to $28-29$ months could avoid lowering the yield grade of Hanwoo. The changes in the lean meat production of the individual primal cuts of Hanwoo beef according to yield grade have been shown in Table 6. Among the ten primal cuts of Hanwoo beef, tenderloin, striploin, chuck, shoulder, and bottom round did not differ according to yield grade. Yield grades $\mathrm{B}$ and $\mathrm{C}$ have shown significantly higher production of prime cuts sirloin, top round, and brisket. Yield grade $\mathrm{C}$, on the other hand, has shown higher production of shank and ribs than the other two yield grades. It can be implied that increased production of shank and ribs could lower the yield grade of Hanwoo. In addition, increased production of sirloin, top round, and brisket could give Hanwoo a yield grade of $\mathrm{B}$ and $\mathrm{C}$. 


\section{Correlation of carcass yield traits with primal cuts yield}

The distribution of muscle, fat, and bone change as the cattle mature over time. Factors affecting the fat deposition and distribution of tissue such as gender, breed, and energy partitioning have been identified and established years ago [30,31] but few have studied the tissue distribution to different parts of the cattle. The simple correlation between the carcass traits and the primal cuts yield was shown in Table 7 . The correlation coefficients between the slaughter age and the ten primal cuts were 0.14 to 0.23 indicating a low significant positive correlation $(p<0.001)$. Market weight correlation among the ten primal cuts was observed highest in the ribs at 0.84 followed by sirloin and top round at 0.77 , shoulder at 0.75 , strip loin and bottom round at 0.72 , brisket at 0.70 , tenderloin and chuck at 0.67 , and the lowest in shank at $0.55(p<0.001)$. The correlation of CCW among the ten primal cuts was observed highest in the ribs and sirloin (0.89 and 0.81) followed by top round, shoulder, and strip loin $(0.78,0.77,0.75)$ which is consistent with previous reports $[5,24]$. The BFT did not show a significant correlation with tenderloin, chuck, and shoulder, and showed a low significant positive correlation to the other seven primal cuts (0.11 to 0.42$)$. The highest positive correlation of the REA was observed in striploin at 0.71 and sirloin at 0.63 $(p<0.001)$. The dressing percentage showed a significant positive correlation ranging from 0.19 to 0.44 with all the ten primal cuts of Hanwoo beef $(p<0.001)$, while the yield index showed a significant negative correlation with all the ten primal cuts except tenderloin, chuck, and bottom round. Among the factors determining the Hanwoo meat quality, the MS showed a significant positive correlation with the sirloin at $0.21(p<0.001)$, strip loin at $0.15(p<0.001)$, and ribs at $0.17(p<0.01)$. Among the ten primal cuts, tenderloin, sirloin, strip loin, and ribs have shown the highest overall acceptability due to their increased fat content and tenderness [4]. Generally, these prime cuts cost the most among other prime cuts. Rib prime cut is notable for its high marbling, tenderness, and distinctive flavor while the loin parts (tenderloin, sirloin, striploin) located directly behind the ribs are not heavily used therefore, has increased tenderness. By increasing the market weight and age of the Hanwoo, CCW and REA of tenderloin were significantly increased. By increasing the market weight and age of the Hanwoo, CCW, REA, and BFT of sirloin and striploin were increased. However, the increased BFT for the two prime cuts reduced the MYI of the respective cuts. In terms of marbling, market weight and age were positively correlated with MS in sirloin and striploin. The MS of the rib prime cut was also positively related with market weight and age. The rib prime cut was also the most positively correlated with slaughter age, market weight, $\mathrm{CCW}, \mathrm{REA}$, and BFT. The highly positive correlation of BFT with rib prime cut consequently showed the highest negative correlation of MYI. Altogether, increasing the market weight and age

Table 7. Correlation coefficients between carcass traits and Hanwoo primal cuts yield

\begin{tabular}{|c|c|c|c|c|c|c|c|c|c|c|}
\hline Trait & $\begin{array}{c}\text { Tenderloin } \\
(\mathbf{k g})\end{array}$ & $\begin{array}{c}\text { Sirloin } \\
(\mathrm{kg})\end{array}$ & $\begin{array}{l}\text { Strip loin } \\
\text { (kg) }\end{array}$ & $\begin{array}{c}\text { Chuck } \\
\text { (kg) }\end{array}$ & $\begin{array}{c}\text { Shoulder } \\
\text { (kg) }\end{array}$ & $\begin{array}{l}\text { Bottom } \\
\text { round }(\mathbf{k g})\end{array}$ & $\begin{array}{l}\text { Top round } \\
(\mathrm{kg})\end{array}$ & $\begin{array}{c}\text { Brisket } \\
\text { (kg) }\end{array}$ & $\begin{array}{c}\text { Shank } \\
(\mathrm{kg})\end{array}$ & $\begin{array}{l}\text { Rib } \\
\text { (kg) }\end{array}$ \\
\hline Slaughter age (month) & $0.20^{* * *}$ & $0.22^{* * *}$ & $0.18^{* * *}$ & $0.17^{\star \star *}$ & $0.21^{\star * *}$ & $0.20^{\star * *}$ & $0.23^{* * *}$ & $0.16^{\star * *}$ & $0.14^{* *}$ & $0.17^{\star * *}$ \\
\hline Market weight (kg) & $0.67^{* * *}$ & $0.77^{\star * \star}$ & $0.72^{\star * *}$ & $0.67^{\star * *}$ & $0.75^{\star \star *}$ & $0.72^{* * *}$ & $0.77^{* * *}$ & $0.70^{\star * *}$ & $0.55^{\star \star *}$ & $0.84^{* * *}$ \\
\hline Carcass cold weight (kg) & $0.70^{* * *}$ & $0.81^{* * *}$ & $0.75^{\star \star *}$ & $0.69^{* * *}$ & $0.77^{* * *}$ & $0.73^{\star * *}$ & $0.78^{* * *}$ & $0.73^{\star \star \star}$ & $0.55^{\star \star *}$ & $0.89^{* * *}$ \\
\hline Backfat thickness (mm) & 0.02 & $0.20^{\star * \star}$ & $0.16^{* * *}$ & $0.06^{* * *}$ & 0.09 & 0.05 & $0.12^{*}$ & $0.11^{*}$ & $0.15^{\star *}$ & $0.42^{* * *}$ \\
\hline Ribeye area $\left(\mathrm{cm}^{2}\right)$ & $0.50^{* * *}$ & $0.63^{\star * \star}$ & $0.71^{\star * *}$ & $0.47^{\star \star \star}$ & $0.52^{\star \star \star}$ & $0.56^{\star \star *}$ & $0.55^{\star \star \star}$ & 0.46 & $0.36^{* * *}$ & $0.45^{\star \star \star}$ \\
\hline Yield index & -0.04 & $-0.19^{* * *}$ & $-0.11^{*}$ & -0.08 & $-0.12^{*}$ & -0.06 & $-0.13^{\star *}$ & $-0.15^{\star *}$ & $-0.16^{* *}$ & $-0.47^{* * *}$ \\
\hline Marbling score ${ }^{1)}$ (no.) & -0.04 & $0.21^{* * *}$ & $0.15^{\star *}$ & -0.04 & -0.04 & -0.07 & -0.02 & -0.07 & -0.04 & $0.17^{* * *}$ \\
\hline
\end{tabular}

${ }^{1)}$ Marbling Score: 1-trace, 9-very abundant.

${ }^{*} p<0.05,{ }^{* *} p<0.01,{ }^{* * *} p<0.001$. 
Table 8. Multiple regression analysis and contribution of carcass traits and primal cuts of Hanwoo

\begin{tabular}{|c|c|c|c|c|c|c|c|c|}
\hline \multirow{2}{*}{ Dependent variable } & \multicolumn{4}{|c|}{ Independent variable } & \multirow{2}{*}{$R^{2}$} & \multicolumn{3}{|c|}{ Contribution (\%) } \\
\hline & Intercept & CCW (kg) & BFT (mm) & $\operatorname{REA}\left(\mathrm{cm}^{2}\right)$ & & CCW (kg) & BFT (mm) & $\operatorname{REA}\left(\mathrm{cm}^{2}\right)$ \\
\hline Tenderloin (kg) & 1.18639 & 0.01042 & -0.04346 & 0.00889 & $0.61^{* * *}$ & 75.17 & 22.53 & 2.30 \\
\hline Strip loin (kg) & -1.15726 & 0.01357 & -0.03729 & 0.04861 & $0.71^{\star \star *}$ & 59.87 & 7.80 & 32.34 \\
\hline Chuck (kg) & -2.1031 & 0.03897 & -0.14236 & 0.02521 & $0.57^{* \star *}$ & 80.15 & 18.44 & 1.41 \\
\hline Top round (kg) & 1.96606 & 0.07005 & -0.21784 & 0.06382 & $0.69^{\star \star \star}$ & 83.22 & 13.87 & 2.91 \\
\hline Brisket (kg) & 4.66717 & 0.09262 & -0.27806 & 0.03161 & $0.59^{\star \star \star}$ & 86.18 & 13.39 & 0.42 \\
\hline Shank (kg) & 7.00651 & 0.02923 & -0.06035 & 0.01698 & $0.32^{\star \star \star}$ & 91.94 & 6.76 & 1.31 \\
\hline $\operatorname{Rib}(\mathrm{kg})$ & 1.26539 & 0.16837 & 0.01077 & -0.0535 & $0.79^{\star \star \star}$ & 99.57 & 0.01 & 0.42 \\
\hline
\end{tabular}

${ }^{*} p<0.05,{ }^{* *} p<0.01,{ }^{* * *} p<0.001$.

CCW, carcass cold weight; BFT, backfat thickness; REA, ribeye area.

in sirloin, strip loin, and rib prime cuts could increase CCW, REA, BFT, and dressing percentage but could decrease MYI. Hence, it is important to determine the optimum market weight and slaughter age at which the best meat yield is produced which in this study is suggesting at 28 months. Nevertheless, the MS of the sirloin, strip loin, and ribs increased with increasing slaughter age and time. Slaughter age and market weight showed a positive correlation to these four cuts indicating that increasing production yield of tenderloin, sirloin, strip loin, and the ribs could be managed by prolonged growth of Hanwoo. Increasing the beef quality of sirloin, strip loin, and ribs as affected by marbling can be managed by increasing slaughter age and market weight as shown in the correlation analysis result.

\section{Multiple regression analysis}

The regression analysis and the contribution of carcass traits according to primal cuts yield were shown in Table 8. The regression coefficients by carcass traits that affect the production of prime cuts of beef showed that all ten prime cuts showed positive regression coefficients with CCW and negative regression coefficients with BFT. The REA also showed a positive regression coefficient in all prime cuts except the ribs. These findings imply that CCW and REA positively affect the yield of the prime cuts of Hanwoo beef while the BFT negatively affects the primal cut yield of the Hanwoo beef. In terms of a contribution analysis, the highest contribution predicting the production yield of all the prime cuts of Hanwoo beef was observed in CCW among the carcass traits. The contribution analysis implies that $\mathrm{CCW}$ contributes as a driving factor in measuring the yield of the prime cuts. The CCW could highly affect the meat yield measurement of the ten prime cuts. Taken together, CCW, BFT, and REA were relevant factors in the production of the ten primal cuts of the Hanwoo.

\section{CONCLUSION}

CCW, REA, and BFT all increased as the market weight increased, and the MYI increased as the market weight decreased. The production yield of all prime cuts increased with increasing market weight. In terms of slaughter age, CCW, REA, and BFT all increased from 25 months to 28 months, and the production yield of all prime cuts also increased with increasing slaughter age. According to the meat yield grade, $\mathrm{CCW}$ and $\mathrm{BFT}$ increased from grade $\mathrm{A}$ to grade $\mathrm{C}$, although 
the REA was not affected. The combined findings of the study suggest that slaughtering Hanwoo at the weight of $651-700 \mathrm{~kg}$ and $701-750$ and age of 28.23 and 29.83 months might be desirable to achieve the best quality and quantity grade of Hanwoo beef. However, the positive correlation of CCW and BFT, and the negative correlation of the yield index according to primal cuts yield indicated that it is necessary to couple the slaughtering management of cattle with improved genetic and breeding method of Hanwoo to increase the production yield of the major prime cuts of Hanwoo beef.

\section{REFERENCES}

1. Hwang YH, Kim GD, Jeong JY, Hur SJ, Joo ST. The relationship between muscle fiber characteristics and meat quality traits of highly marbled Hanwoo (Korean native cattle) steers. Meat Sci. 2010;86:456-61. https://doi.org/10.1016/j.meatsci.2010.05.034

2. Jeremiah LE, Gibson LL, Aalhus JL, Dugan MER. Assessment of palatability attributes of the major beef muscles. Meat Sci. 2003;65:949-58. https://doi.org/10.1016/S03091740(02)00307-8

3. Ministry of Food and Drug Safety. Method for labeling and division of beef and pork meat. Cheongju: Ministry of Food and Drug Safety; 2014. Notice No.: 2014-116.

4. Jung EY, Hwang YH, Joo ST. Chemical components and meat quality traits related to palatability of ten primal cuts from Hanwoo carcasses. Korean J Food Sci Anim. 2015;35:85966. https://doi.org/10.5851/kosfa.2015.35.6.859

5. Seo HW, Van Ba H, Seong PN, Kim YS, Kang SM, Seol KH, et al. Relationship between body size traits and carcass traits with primal cuts yields in Hanwoo steers. Anim Biosci. 2021;34:127-33. https://doi.org/10.5713/ajas.19.0809

6. MFAFF [Ministry for Food, Agriculture, Forestry, and Fisheries]. Processing standard for meat products act: grading, fabrication and cutting of beef carcass. Seoul, Korea: Ministry for Food, Agriculture, Forest and Fisheries; 2007.p. 82.

7. Korean Institute for Animal Products Quality Evaluation. Annual report for animal products research [Internet]. Korean Institute for Animal Products Quality Evaluation. 2016 [cited 2021 Nov 10]. https://www.ekapepia.com/home/homeIndex.do

8. Chung KY, Chang SS, Lee EM, Kim HJ, Park BH, Kwon EG. Effects of high energy diet on growth performance, carcass characteristics, and blood constituents of final fattening Hanwoo steers. CNU J Agric Sci. 2015;42:261-8. https://doi.org/10.7744/cnujas.2015.42.3.261

9. Park GB, Moon SS, Ko YD, Ha JK, Lee JG, Chang HH, et al. Influence of slaughter weight and sex on yield and quality grades of Hanwoo (Korean native cattle) carcasses. J Anim Sci. 2002;80:129-36. https://doi.org/10.2527/2002.801129x

10. Korea Institute for Animal Products Quality Evaluation. Marketing livestock and meat in the Korea. Examination and research report [Internet]. Korea Institute for Animal Products Quality Evaluation. 2011 [cited 2021 Nov 10]http://www.ekapepia.or.kr

11. Chung KY, Lee SH, Cho SH, Kwon EG, Lee JH. Current situation and future prospects for beef production in South Korea - a review. Asian-Australas J Anim Sci. 2018;31:951-60. https://doi.org/10.5713/ajas.18.0187

12. Moon SS, Hwang IH, Jin SK, Lee JG, Joo ST, Park GB. Carcass traits determining quality and yield grades of Hanwoo steers. Asian-Australas J Anim Sci. 2003;16:1049-54. https://doi. org/10.5713/ajas.2003.1049

13. eKAPEpia. Grade evaluation of cattle [Internet]. Korea Institute for Animal Products Quality Evaluation. 2017 [cited 2021 Nov 1]. https://www.ekapepia.com/user/distribution/distDetail. 
do?nd1906

14. SAS Institute. SAS/STAT 9.3 user's guide. Cary, NC: SAS Institute; 2011.

15. Lee JM, Hah KH, Kim JH, Cho SH, Seong PN, Jung MO, et al. Study on the carcass yield grade traits and prediction of retail product weight in Hanwoo beef. Korean J Food Sci Anim. 2008;28:604-9. https://doi.org/10.5851/kosfa.2008.28.5.604

16. Kim DJ, Lee CW, Lee CY, Kim JB. The influence of carcass traits on carcass price in mature Hanwoo cow. J Anim Sci Technol. 2010;52:157-64. https://doi.org/10.5187/ JAST.2010.52.2.157

17. Ríos-Utrera A, Cundiff LV, Gregory KE, Koch RM, Dikeman ME, Koohmaraie M, et al. Genetic analysis of carcass traits of steers adjusted to age, weight, or fat thickness slaughter endpoints.J Anim Sci. 2005;83:764-76. https://doi.org/10.2527/2005.834764x

18. Park SJ, Beak SH, Jung DJS, Kim SY, Jeong IH, Piao MY, et al. Genetic, management, and nutritional factors affecting intramuscular fat deposition in beef cattle - a review. AsianAustralas J Anim Sci. 2018;31:1043-61. https://doi.org/10.5713/ajas.18.0310

19. Kim JH, Ba HV, Seong PN, Kim YS, Kang SM, Cho SH, et al. Carcass characteristics and primal cuts yields by live weight of Hanwoo steers in Gyeongbuk province. J Agric Life Sci. 2018;52:151-67. https://doi.org/10.14397/jals.2018.52.2.151

20. Boleman SL, Boleman SJ, Morgan WW, Hale DS, Griffin DB, Savell JW, et al. National Beef Quality Audit-1995: survey of producer-related defects and carcass quality and quantity attributes. J Anim Sci. 1998;76:96-103. https://doi.org/10.2527/1998.76196x

21. Miller MF, Kerth CR, Wise JW, Lansdell JL, Stowell JE, Ramsey CB. Slaughter plant location, USDA quality grade, external fat thickness, and aging time effects on sensory characteristics of beef loin strip steak. J Anim Sci. 1997;75:662-7. https://doi.org/10.2527/1997.753662x

22. Yoon JH, Won JI, Lee KS, Kim JB, Lee JK. Estimation of reasonable market month of age for Hanwoo steer. J Anim Sci Technol. 2013;55:405-16. https://doi.org/10.5187/ JAST.2013.55.5.405

23. Iwamoto E, Oka A, Iwaki F. Effects of the fattening period on the fatty acid composition of fat deposits and free amino acid and inosinic acid contents of the longissimus muscle in carcasses of Japanese Black steers. Anim Sci J. 2009;80:411-7. https://doi.org/10.1111/j.17400929.2009.00648.x

24. Lee SC, Choi HH, Shin JS, Kim KH, Oh YK, Cheon DW. Carcass characteristics and profitability analysis based on slaughter age of Hanwoo steers. J Anim Sci Technol. 2013;55:315-23. https://doi.org/10.5187/JAST.2013.55.4.315

25. Kim KH, Lee JH, Oh YG, Kang SW, Lee SC, Park WY, et al. The optimal TDN levels of concentrates and slaughter age in Hanwoo steers. J Anim Sci Technol. 2005;47:731-44. https:// doi.org/10.5187/JAST.2005.47.5.731

26. Lee JG, Lee SS, Cho KH, Cho C, Choy YH, Choi JG, et al. Correlation analyses on body size traits, carcass traits and primal cuts in Hanwoo steers. J Anim Sci Technol. 2013;55:351-8. https://doi.org/10.5187/JAST.2013.55.5.351

27. Cho H, Jung YB, Kim BD, Jung S, Seo S. Assessment of the effects of carcass traits and slaughter age on the carcass grades of Hanwoo steers based on the revised grading system of beef carcasses.J Agric Life Sci. 2020;54:69-76. https://doi.org/10.14397/jals.2020.54.2.69

28. Lee J, Choi S, Dang C, Kang SN, Kim N. The effect of carcass traits on economic values in Hanwoo. Korean J Food Sci Anim Resour. 2011;31:603-8. https://doi.org/10.5851/ kosfa.2011.31.4.603

29. Rhee YJ, Jeon KJ, Choi SB, Seok HK, Kim SJ, Lee SK, et al. Prediction of carcass yield by ultrasound in Hanwoo. J Anim Sci Technol. 2003;45:335-42. https://doi.org/10.5187/ 
JAST.2003.45.2.335

30. Jones SDM. Carcass tissue yield and distribution in three biological types of cattle fed grain or forage-based diets. Can J Anim Sci. 1985;65:363-74. https://doi.org/10.4141/cjas85-042

31. Patterson DL, Price MA, Berg RT. Patterns of muscle, bone, and fat accretion in three biological types of feedlot bulls fed three dietary energy levels. Can J Anim Sci. 1985;65:35161. https://doi.org/10.4141/cjas85-041 